DOI 10.22460/jpmi.v1i3.361-370

\title{
ANALISIS HUBUNGAN SELF EFFICACY TERHADAP KEMAMPUAN BERPIKIR KRITIS MATEMATIS SISWA PADA MATERI LINGKARAN
}

\author{
Sinta Nurazizah ${ }^{1}$, Adi Nurjaman ${ }^{2}$ \\ ${ }^{1,2}$ IKIP Siliwangi, Jl. Terusan Jenderal Sudirman, Cimahi, Jawa Barat, Indonesia \\ ${ }^{1}$ nurazizahshinta@gmail.com, ${ }^{2}$ nurjamanadi@ikipsiliwangi.ac.id
}

Diterima: 19 April 2018; Disetujui: 28 Mei 2018

\begin{abstract}
This study aims to analyze connection self-efficacy toward the ability of critical thinking on the material of circe of junior high school students. This research method using the qualitative descriptive method. This research is conducted in SMP Negeri 9 Cimahi in Grade IX of the academic year 2017-2018. The population of this study is the students of class IX SMP Negeri 9 and the subject of the research is all the students of class IX-A that consist of 34 students. To obtain the research data used the instrument in the form of test description and questionnaire self-efficacy. The results of the research concluded: (1) the level of students' mathematical critical thinking ability in the problem solution is still low; (2) students' difficulties, in general, have not understood the problem and the preconception is still low; (3) students have not embedded the sense of learning independently; (4) there are connection which is significant between self-efficacy toward mathematics critical thinking.
\end{abstract}

Keywords: Mathematical Critical Thinking, Self-Efficacy

\begin{abstract}
Abstrak
Penelitian ini bertujuan untuk menganalisis hubungan self efficacy terhadap kemampuan berpikir matematis pada materi lingkaran siswa SMP. Metode penelitian ini menggunakan metode deskriptif kualitatif. Tempat penelitian dilaksanakan di SMP Negeri 9 Cimahi pada kelas IX semester ganjil tahun ajaran 2017-2018. Populasi penelitian ini adalah siswa kelas IX SMP Negeri 9 Cimahi dan Subjek penelitian adalah seluruh siswa kelas IX-A yang terdiri dari 34 orang siswa. Untuk memperoleh data penelitian digunakan instrumen berupa tes soal uraian dan angket self efficacy. Hasil penelitian didapat kesimpulan: (1) tingkat kemampuan berpikir kritis matematis siswa dalam penyelesaian soal masih tergolong rendah; (2) kesulitan siswa pada umunya belum memahami soal dan prakonsep cukup rendah; (3) kurangnya rasa percaya akan kemampuan yang dimiliki siswa. (4) terdapat hubungan yang signifikan antara self efficacy terhadap kemampuan berpikir kritis matematis siswa.
\end{abstract}

Kata Kunci: Berpikir Kritis Matematis, Self Efficacy

How to cite: Nurazizah, S., \& Nurjaman, A. (2018). Analisis Hubungan Self Efficacy terhadap Kemampuan Berpikir Kritis Matematis Siswa pada Materi Lingkaran. JPMI - Jurnal Pembelajaran Matematika Inovatif, 1 (3), 361-370.

\section{PENDAHULUAN}

Matematika sebagai suatu disiplin ilmu yang lebih mengutamakan proses berpikir, dan di dalamnya terkandung aspek-aspek substansial yang menuntun siswa untuk berpikir logis menurut pola dan aturan yang telah tersusun baku. Sutjipto (Malia, Dodik, \& Reny, 2017) Matematika merupakan salah satu pelajaran yang penting dikuasai siswa di sekolah karena 
banyak kegunaannya dalam kehidupan sehari-hari oleeh karena itu di sekolah matematika mempunyai peranan yang cukup besar dalam kemampuan berpikir kritis untuk memecahkan masalah yang berkaitan dengan kehidupan sehari-hari

Reason (Hendriana, Rohaeti, \& Sumarmo, 2017) mengemukakan berpikir adalah proses mental seseorang yang lebih dari sekedar mengingat dan memahami. Mengingat pada dasarnya hanya melibatkan usaha penyimpanan sesuatu yang telah dialami yang suatu saat dikeluarkan kembali, sedangkan memahami memerlukan pemerolehan sesuatu yang didengar dan dibaca serta melihat keterkaitan antar aspek dalam memori. Dengan kata lain, melalui berpikir seseorang dapat bertindak melebihi dari informasi yang diterimanya.Ditinjau dari kemampuan berpikir matematis, kemampuan berpikir kritis matematis merupakan salah satu bagian terpenting dari kemampuan berpikir matematis yang perlu dikembangkan. Dengan berpikir kritis, siswa akan tanggap terhadap permasalahan yang ada, sehingga mampu menyaring setiap informasi yang diterima dengan baik.

Pengembangan kemampuan berpikir, khususnya yang mengarah pada berpikir tingkat tinggi, perlu mendapat perhatian serius karena sejumlah hasil studi seperti Henningsen dan Stein, 1997; Peterson, 1988; Mullis, dkk (Nurjaman, 2015) menunjukkan, "Pembelajaran matematika pada umumnya masih berfokus pada pengembangan kemampuan berpikir tahap rendah yang bersifat prosedural". Untuk siswa yang memiliki tingkat kecerdasan tinggi, sikap dan tindakan serta cara mengajar yang dilakukan oleh guru tidak menjadi masalah. Tetapi, bagi siswa yang memiliki tingkat kecerdasan rata-rata, dan rendah pelajaran matematika akan menjemukan dan mengakibatkan tidak senang belajar matematika.

Dalam mengembangkan penguasaan konsep pelajaran yang baik, kemampuan berpikir kritis matematis siswa sangat dibutuhkan, ketika siswa mengerjakan soal yang diberikan cenderung membutuhkan daya analisis dan berpikir secara logis, hal ini sejalan dengan Novianty (2017), Berpikir kritis matematis merupakan dasar proses berpikir untuk menganalisis argumen dan memunculkan gagasan terhadap tiap makna untuk mengembangkan pola pikir secara logis. Oleh karena itu, sangat penting untuk memberikan kesempatan kepada siswa agar menggunakan keterampilan berpikirnya baik dalam melakukan pendugaan-pendugaan berdasarkan pengalaman atau sepengetahuannya sendiri, sehingga lebih mudah memahami konsep. Berpikir kritis tidak ekuivalen dengan keterampilan berpikir tingkat tinggi Dalam berpikir kritis termuat semua komponen berpikir tingkat tinggi, namun juga memuat disposisi berpikir kritis yang tidak termuat dalam berpikir tingkat tinggi. Ennis (Sumarmo, Hidayat, Zukarnaen, Hamidah, \& Sariningsih, 2012) mendefinisikan berpikir kritis sebagai berpikir reflektif yang beralasan dan difokuskan pada penetapan apa yang dipercayai atau yang dilakukan. Hal ini bertujuan agar potensi yang dimiliki siswa dapat terus meningkat dan berkembang secara optimal. Selain itu, kepercayaan akan kemampuan yang dimilikinya, sistematis dan terbuka terhadap perkembangan ilmu pengetahuan. Untuk mencapai kemampuan berpikir kritis matematis dalam pembelajaran khususnya dalam pembelajaran matematika siswa memerlukan perilaku yang memadai salah satunya kemampuan diri (self efficacy).

Kemampuan diri (self efficacy) adalah kepercayaan seseorang terhadap kemampuannya dalam mengkoordinasikan keterampilan dan kemampuan untuk mencapai tujuan yang diinginkan dalam domain dan keadaan tertentu" (Hendriana et al., 2017). Dengan kata lain kemampuan diri (self effacy) adalah keyakinan individu dalam menghadapi dan menyelesaikan masalah yang dihadapinya diberbagai situasi serta mampu menentukan tindakan dalam menyelesaikan tugas atau masalah tertentu, sehingga individu tersebut mampu mengetasi rintangan dan 
mencapai tujuan yang diharapkan. Canfields \& Watkins (Hendriana et al., 2017) Kesuksesan individu antara lain dapat ditentukan oleh pandangan dirinya terhadap kemampuannya. Satu jenis pandangan terhadap kemampuan dirinya yaitu yang dapat mempengaruhi kesuksesan individu. Dengan self efficacy, siswa percaya bahwa dia bisa menyelesaiakan masalah atau soal serta dapat mengukur sejauhmana kemampuan diri sendiri akan memahami, menalar, menganalisis dan mengerjakan suatu soal atau masalah. Istilah self efficacy melukiskan prilaku yang disertai dengan kedisiplinan dan upaya melakukan tindakan yang lebih bijak dan cerdas.

Berdasarkan studi pendahuluan, masih banyak siswa yang belum megoptimalkan kemampuan berpikir khususnya dalam berpikir tingkat tinggi (high order thinking) serta self efficacy masih menjadi hambatan. Beranekaragam tingkat kesulitan yang dialami siswa mulai dalam kurang percaya akan kemampuan yang dimiliki dan menganggap kemampuan yang dimiliki temannya lebih baik dari yang dimilikinya, kurang suka terhadap mata pelajarannya, kurang paham terhadap konsep yang diajarkan hingga kurang dorongan atau motivasi dalam belajar. Hal ini sangat berpengaruh terhadap hasil belajar yang dicapai juga karakter yang tertanam akan jauh dari yang diharapkan.

Lingkaran merupakan salah satu materi matematika pra syarat untuk konsep materi matematika berikutnya. Dalam matematika, materi ini akan berkaitan dengan konsep trigonometri yang nantinya akan dipelajari di jenjang SMA serta bisa membantu dalam menyelesaikan soal-soal geometri, terutama soal lingkaran yang berkaitan dengan kehidupan sehari-hari. Berdasarkan hasil observasi di kelas dalam mengerjakan soal berpikir kritis matematis pada materi lingkaran, banyak siswa mengalami kesulitan dalam pengerjaannya, siswa masih terlihat kebingungan dalam upaya menyelesaikan soal-soal tersebut. Siswa tidak dapat menyusun bukti dengan lengkap dan runtut untuk menarik kesimpulan. Siswa juga berkesulitan dalam memeriksa kesahihan suatu argumen. Kemampuan menduga siswa dalam menyelesaikan permasalahan matematika masih sangat kurang. Siswa harus sering diarahkan dan dimotivasi, serta nilai hasil pembelajarannya belum memuaskan, masih banyak siswa yang ragu akan kemampuan yang dimilikinya hal ini mengakibatkan siswa lebih percaya terhadap pendapat temannya sendiri dibandingkan dengan pendapat yang dimilikinya yang belum tentu kebenarannya. Oleh karena itu, perlu sebuah analisis untuk mengetahui hubungan self efficacy terhadap kemampuan berpikir kritis matematis siswa. Analisis hubungan self efficacy terhadap kemampuan berpikir kritis matematis mengacu pada jenis-jenis penyebab kesulitan kemampuan penalaran matematis dan kurangnya kepercayaan pada kemampuan yang dimiliki siswa SMP Negeri 9 Cimahi kelas IX yang dikemukakan oleh peneliti. Halpen "Berpikir kritis adalah memberdayakan keterampilan atau strategi kognitif dalam menentukan tujuan". Berpikir kritis membuat seseorang untuk berpikir dahulu sebelum bertindak, sehingga memiliki kemampuan berpikir kritis tidak hanya bagi siswa yang masih mengenyam di bangku sekolah, dewasa sekalipun sangat penting memiliki kemampuan berpikir kritis agar tidak gegabah dalam bertindak (Hendriana, Rohaeti, \& Hidayat, 2017; Hendriana, Hidayat, \& Ristiana, 2018; Hidayat, 2011; 2012; Sumarmo, Hidayat, Zukarnaen, Hamidah, \& Sariningsih, 2012; Sumarmo, Mulyani, \& Hidayat, 2018; Tresnawati, Hidayat, \& Rohaeti, 2017).

Indikator berpikir kritis menurut Ennis (Suwarma, 2009) adalah (1) Memberikan penjelasan sederhana, meliputi:fokus pada pertanyaan, menganalisa argument, mengklarifikasi pertanyaan, dan jawaban; (2) membangun keterampilan dasar, meliputi: mempertimbangkan kredibilitas (kriteria) suatu sumber informasi, mengobservasi dan mempertimbangkan hasil observasi; (3) menyimpulkan (Inference), meliputi; membuat deduksi dan mempertimbangkan 
hasil deduksi, membuat dan mempertimbangkan nilai suatu keputusan; (4) membuat penjelasan lebih lanjut (Advanced clarification) meliputi: mendefinisikan istilah, mempertimbangkan definisi, mengidentifikasi asumsi; (5) Strategi dan taktik, meliputi: memutuskan tindakan, berinteraksi dengan orang lain.

Adapun Indikator kemampuan diri (self efficacy) yang dirinci dari ketiga dimensi kemampuan diri yaitu: (1) Dimensi magnitude, yaitu bagaimana siswa dapat mengatasi kesulitan belajarnya yang meliputi a) berpandangan positif dalam mengerjakan pelajaran dan tugas; b) seberapa besar minat terhadap pelajaran dan tugas; c) mengembangkan kemampuan dan prestasi; d) melihat tugas yang sulit sebagai suatu tantangan; e) belajar sesuai dengan jadwal yang diatur; f) bertindak selektif daam mencapai tujuannya. (2) Dimensi strength, yaitu seberapa tinggi keyakinan siswa dalam mengatasi kesulitan belajarnya, yang meliputi: a) usaha yang dilakukan dapat meningkatkan prestasi dengan baik; b) komitmen dalam menyelesaikan tugas-tugas yang diberikan; c) percaya dan mengetahui keunggulan yang dimiliki d) kegigihan dalam menyelesaikan tugas; e) memiliki tujuan positif dalam melakukan berbagai hal; f) memiliki motivasi yang baik terhadap dirinya sendiri untuk pengembangan dirinya. (3) Dimensi generality, yaitu menunjukan apakah keyakinan kemampuan diri akan berlangsung dalam domain tertentu atau berlaku dalam berbagai aktivitas dan situasi yang meliputu: a) menyikapi situasi yang berbeda dengan baik dan berpikir positif; b) menjadikan pengalaman yang lampau sebagai jalan mencapai kesuksesan; c) suka mencari situasi baru; d) dapat mengatasi segala situasi dengan elektif; dan e) mencoba tantangan baru (Hendriana et al., 2017; Rahmi, Nadia, Hasibah, \& Hidayat, 2017).

Kemampuan siswa di dalam kelas dapat terkondisi dengan memungkinkan siswa membiasakan diri berpikir secara mendalam. Pada umumnya pembelajaran matematika dirasa pembagian waktunya sangat kurang karena mata pelajaran matematika merupakan salah satu mata pelajaran dengan intensitas pengulangan tinggi. Karena hal tersebut upaya yang dapat dilakukan siswa agar hasil belajarnya maksimal adalah melakukan kegiatan kebiasaan berpikir dan yakin akan kemampuan yang ia miliki bahwa ia mampu menyelesaikan persoalan-persoalan yang mereka temukan baik dilingkungan sekolah maupun di luar sekolah.

Kemampuan berpikir kritis siswa dalam sesuatu mata pelajaran adalah bergantung kepada kemampuan akan dirinya. Siswa yang memiliki sikap positif yakin akan kemampuan yang ia miliki bahwa ia dapat menyelesaikan maslah atau persoalan yang dihadapi baik itu sulit maupun sukar mereka cenderung bisa menemuan solusinya. Kemampuan diri merupakan faktor yang menentukan tercapainya kemampuan berpikir kritis siswa. Karena dengan adanya kemampuan diri untuk belajar dalam diri siswa akan memudahkan guru dalam membimbing dan mengarahkan siswa, sehingga akan meminimalisir anggapan siswa bahwa matematika itu hal yang sangat sulit dan membuat siswa percaya diri terhadap apa yang mereka miliki tanpa harus ragu dan takut dalam mengungkapkannya. Dan siswa yang memiliki kebiasaan berpikir cenderung hidup dengan penuh disiplin dan tanggung jawab dalam setiap tindakan dalam menentukan solusi terhadap persoalan yang ia hadapi untuk mencapai prestasi dan hasil belajar yang tinggi.

Berdasarkan latar belakang, hal-hal yang ingin diuraikan yaitu: 1) mengapa siswa SMPN 5 Cimahi kelas IX masih sulit dalam penyelesaian soal berpikir kritis matematis pada materi lingkaran? 2) apa penyebab rendahnya self efficacy siswa dalam menyelesaikan soal berpikir kritis matematis pada materi lingkaran? 3) apakah terdapat hubungan self efficacy terhadap kemampuan berpikir kritis matematis? Fokus penelitian ini adalah untuk melihat penyebab kesulitannya kemampuan berpikir kritis matematis dan kurangnya self efficacy yang 
dilakukan siswa dalam proses penyelesaian soal berpikir kritis serta melihat hubungan antara self efficacy terhadap kemampuan berpikir kritis matematis pada materi lingkaran.

\section{METODE}

Tempat penelitian dilaksanakan di SMP Negri 9 Cimahi, Semester Ganjil Tahun Akademik 2017-2018. Penelitian ini tergolong dalam penelitian deskriptif kualitatif yang berupaya untuk mendeskripsikan analisis kemampuan berpikir kritis matematis dan self efficacy serta hubungan self efficacy terhadap kemampuan berpikir kritis matematis.

Metode yang digunakan pada penelitian ini adalah kualitatif deskriptif. Jenis ini dipilih karena bertujuan untuk menggambarkan kemampuan siswa dalam menyelesaikan soal-soal berpikir kritis matematis. Sampel dari penelitian ini adalah seluruh siswa IX-A di SMP Negri 9 Cimahi. Sampel dipilih secara purposive dengan meminta pendapat guru kelas yang memahami kondisi kognitif dan afektif siswa. Tahap penelitian terbagi menjadi tiga, yaitu perencanaan, pelaksanan dan pelaporan. Pada tahap perencanaan peneliti menyiapkan perangkat instrumen berpikir kritis matematis meliputi kisikisi soal, lembar kerja jawaban dan penskoran, serta menyiapkan perangkat instrumen self efficacy meliputi kisi-kisi angket, bobot angket, dan penskoran. Selanjutnya pada tahap pelaksanaan siswa diberi tes berpikir kritis matematis, setelah itu siswa mengisi angket self efficacy. Pada tahap laporan, peneliti mengolah data yang diperoleh selama penelitian berlangsung dan menyusun laporan. Instrumen utama dalam penelitian ini adalah tes uraian dan angket. Perangkat tes yang digunakan untuk mengumpulkan data dalam berpikir kritis matematis penelitian ini adalah 8 soal berpikir kritis matematis pada materi lingkaran dan perangkat tes yang digunakan untuk mengumpulkan data dalam self efficacy penelitian ini adalah 20 pernyataan negatif dan positif.

Pengolahan data untuk melihat adanya kemampuan berpikir kritis matematis dengan cara melihat jawaban siswa pada lembar jawaban, jawaban siswa yang mengisi kurang tepat dibandingkan dengan jawaban yang sudah benar dan pengolahan data untuk melihat self efficacy siswa dengan cara melihat bobot penskoran angket yang telah diisi siswa, serta pengolahan data untuk melihat adanya hubungan self efficacy antara berpikir kritis matematis dengan cara uji statistika yaitu uji normalitas dan uji korelasi. Jika signifikansinya <0,05 maka $\mathrm{H}_{0}$ ditolak tapi jika signifikansinya $>0,05$ maka $\mathrm{H}_{\mathrm{a}}$ diterima.

\section{HASIL DAN PEMBAHASAN}

\section{Hasil}

Metode penelitian ini adalah deskriptif kualitatif. Penelitian ini dilaksanakan pada siswa kelas IX semester ganjil di SMP Negeri 9 Cimahi tahun ajaran 2017-2018. Jumlah siswa dikelas tersebut adalah 34 orang. Peneliti memberikan 8 butir soal berpikir kritis dengan materi lingkaran. Setelah selesai, siswa diberikan angket untuk mengukur kemampuan afektif saat pembelajaran di kelas, khususnya saat mengerjakan soal-soal yang biasa guru berikan. Selanjutnya hasil data yang diperoleh peneliti olah menggunakan SPSS untuk melihat hubungan antara self efficacy terhadap kemampuan berpikir kritis matematis siswa SMP pada materi lingkaran. Untuk lebih jelasnya perhatikan Tabel di bawah ini. 
Tabel 1. Hasil Uji Normalitas

\begin{tabular}{lcccccc}
\hline & \multicolumn{2}{c}{ Kolmogrov-Smirnov $^{\text {a }}$} & \multicolumn{3}{c}{ Shapiro-Wilk } \\
\cline { 2 - 7 } & Statistic & Df & Sig & Statistic & Df & sig \\
\hline Berpikir kritis matematis & 0.115 & 34 & 0.200 & 0.970 & 34 & 0.472 \\
\hline Self-efficacy & 0.112 & 34 & 0.200 & 0.947 & 34 & 0.099 \\
\hline
\end{tabular}

Tabel 2. Hasil Uji Korelasi

\begin{tabular}{llcc}
\hline & & $\begin{array}{c}\text { Berpikir kritis } \\
\text { matematis }\end{array}$ & Self efficacy \\
\hline Berpikir kritis matematis & Pearson Correlation & 1 & $0.556^{* *}$ \\
& Sig.(2-tailed) & & 0.001 \\
& $\mathrm{~N}$ & 34 & 34 \\
\hline Self efficacy & Pearson Correlation & $0.556^{* *}$ & 1 \\
& Sig.(2-tailed) & 0.001 & 34 \\
& $\mathrm{~N}$ & 34 & 34 \\
\hline
\end{tabular}

Dilihat dari tabel diatas diperoleh signifikansi $=0,200$ dan 0,472. Data dikatakan berdistribusi normal jika signifikansinya $>0,05$. Sehingga data berdistribusi normal dan dilakukan dengan uji korelasi.

\section{Hipotesis:}

$\mathrm{H}_{0}$ : Tidak terdapat hubungan antara self efficacy terhadap kemampuan berpikir kritis matematis siswa SMP pada materi lingkaran.

$\mathrm{H}_{\mathrm{a}}$ : Terdapat hubungan antara self efficacy terhadap kemampuan berpikir kritis matematis siswa SMP pada materi lingkaran.

Dari data diatas didapat pearson correlation $=0,556$ dan signifikan (2-tailed) $=0,01$. Criteria koreasi $\alpha=0,05$, jika signifikansi $>0,05$ maka $\mathrm{H}_{0}$ diterima tapi jika signifikansi $<0,05$ maka $\mathrm{H}_{\mathrm{a}}$ ditolak. Karena $0,01<0,05$ oleh karena itu $\mathrm{H}_{0}$ ditolak. Sehingga dapat disimpulkan bahwa terdapat hubungan antara self efficacy terhadap kemampuan berpikir kritis matematis siswa SMP pada materi lingkaran.

\section{Pembahasan}

Untuk melihat bagaimana kesulitan siswa dalam menyelesaikan soal berpikir kritis matematis dan rendahnya self efficacy siswa akan peneliti deskripsikan dengan membandingkan 2 jawaban siswa yang belum tepat dan yang sudah benar, berikut penjelasannya.

Indikator dari soal nomor 1 adalah memberikan penjelasan sederhana meliputi mengklarifikasi pertanyaan dan jawaban 


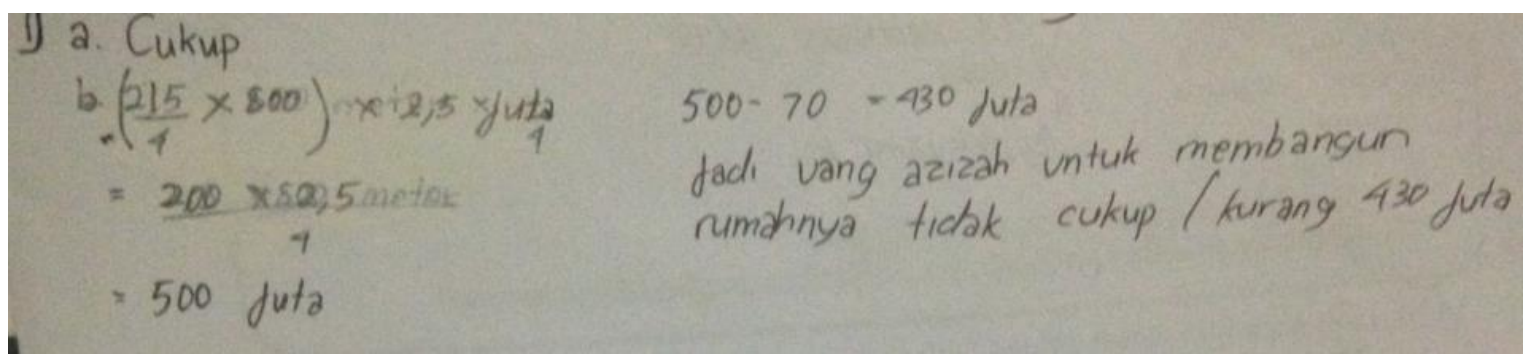

Gambar 1. Jawaban Siswa Yang Sudah Benar

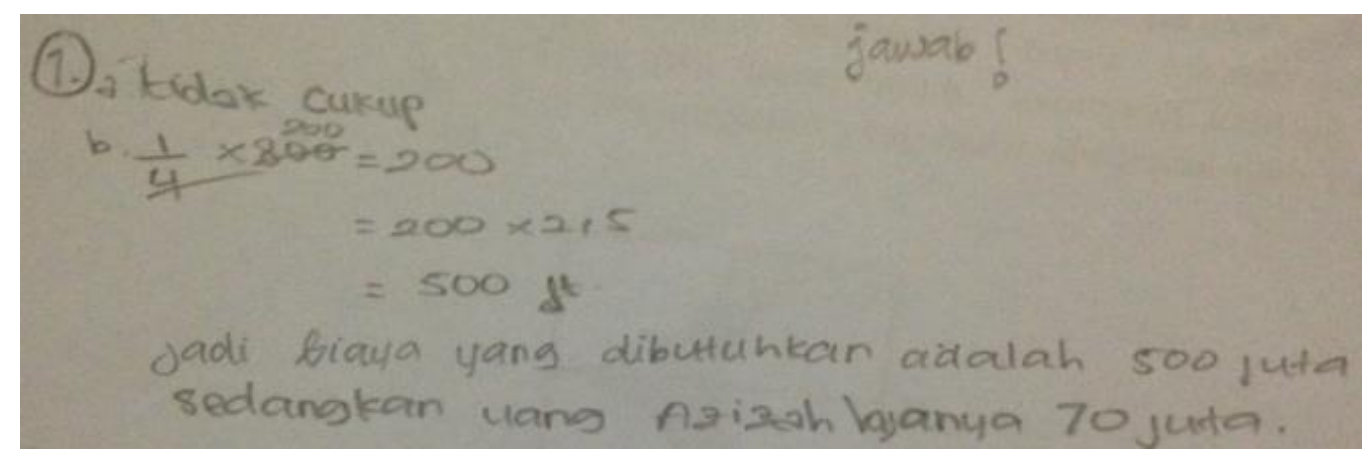

Gambar 2. Jawaban Siswa Yang Kurang Tepat

Berdasarkan jawaban siswa secara prosedural sudah benar baik siswa 1 maupun siswa 2, adapun kesalahan yang dilakukan adalah siswa kurang teliti dalam memahami soal, sehingga Kesalahan siswa yang dilakukan oleh siswa 2 adalah kesalahan dalam menjawab point a, pada point a ditanyakan akan kecukupan data yang diberikan untuk mendapatkan solusi, tapi siswa 2 menjawab tidak cukup data yang diberikan. Padahal jika data yang diberikan tidak cukup tidak harus dikerjakan, hal ini disebabkan karena keragu-raguan dan ketidaktelitian siswa dalam menjawab soal yang diberikan. Sehingga dapat disimpulkan bahwa kemampuan untuk memberikan penjelasan sederhana meliputi mengklarifikasi pertanyaan dan jawaban tergolong sedang bagi siswa 1 dan tergolong kurang bagi siswa 2. Hanya saja perlu ditingkatkan kembali dalam membaca dan memahami soal yang diberikan.

Indikator soal nomor 2 adalah membuat penjelasan lebih lanjut meliputi mengidentifikasi asumsi.

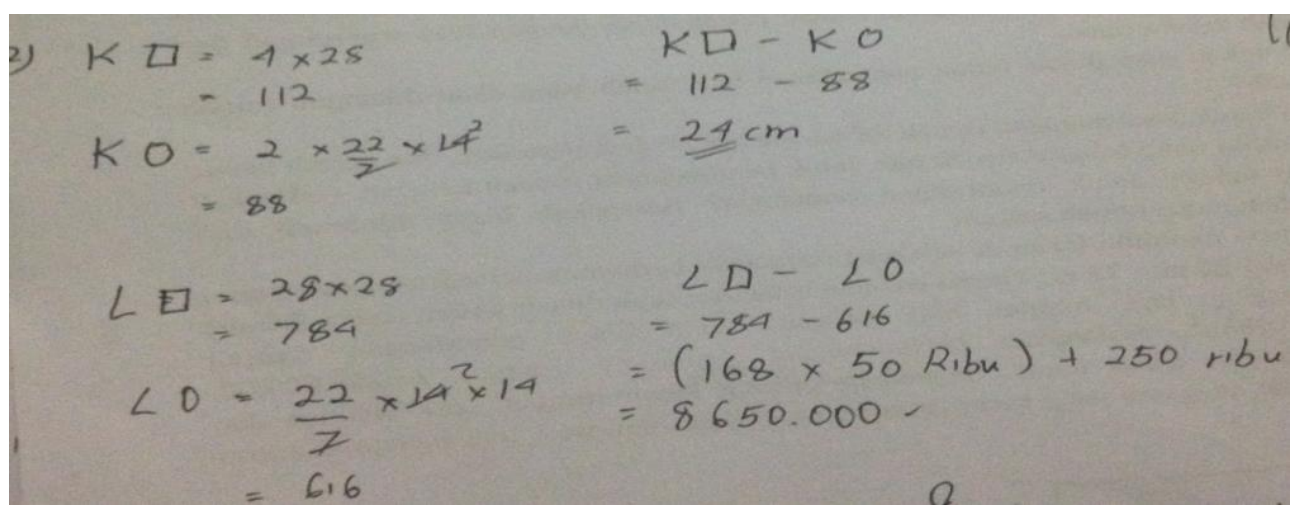

Gambar 3. Jawaban Siswa Sudah Benar 


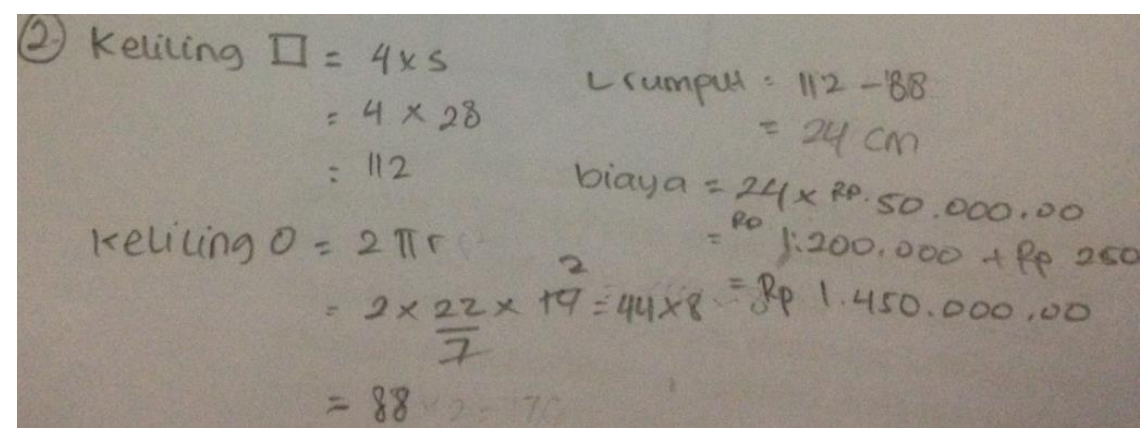

Gambar 4. Jawaban Siswa Kurang Tepat

Berdasarkan jawaban siswa secara prosedural sudah benar baik siswa 1 maupun siswa 2, adapun kesalahan yang dilakukan adalah siswa keliru dalam menentukan solusi dari persoalan yang diberikan dan kurang dapat mengidentifikasi asumsi dengan baik, sehingga kesalahan siswa yang dilakukan oleh siswa 2 adalah kesalahan dalam mentukan solusi akhir dari persoalan yang diberikan. Seharusnya mencari terlebih dahulu luas dari daerah yang diarsir untuk mengetahui budget yang akan dikeluarkan. Tapi siswa 2 menjawab dengan mengalikan keliling dengan biaya yang diperlukan. hal ini disebabkan karena kurangnya penguasaan terhadap materi prasyarat dan kepercayaan akan kemampuan yang dimilikinya serta kurangnya memahami soal yang diberikan. Sehingga dapat disimpulkan bahwa kemampuan untuk membuat penjelasan lebih lanjut meliputi mengidentifikasi asumsi masih tergolong sedang bagi siswa 1 dan tergolong kurang bagi siswa 2. Hanya saja perlu ditingkatkan kembali dalam membaca dan memahami soal yang diberikan.

Indikator soal nomor 3 adalah membangun keterampilan dasar meliputi mempertimbangkan kredibilitas suatu sumber.

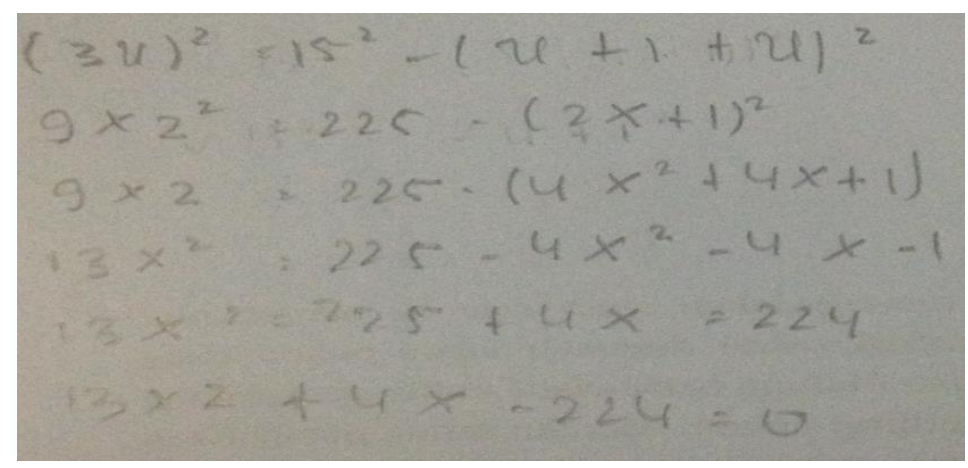

Gambar 5. Jawaban Siswa Sudah Benar

Berdasarkan jawaban siswa secara prosedural cukup baik bagi siswa 1 maupun siswa 2, adapun kesalahan yang dilakukan adalah siswa keliru dalam menentukan solusi dari persoalan yang diberikan dan rendahnya kemampuan siswa dalam mempertimbangkan kredibilitas suatu sumber, sehingga kesalahan siswa yang dilakukan oleh siswa 2 adalah kesalahan dalam mentukan solusi dari persoalan yang diberikan. Kurangnya penguasaan terhadap materi prasyarat dan kepercayaan akan kemampuan yang dimilikinya serta kurangnya memahami soal yang diberikan, mengakibatkan siswa kebingungan dan ragu dalam menentukan solusi dari persoalan yang diberikan dan terjadi miskonsep. Dan untuk 
siswa 1 sudah bisa untuk mentukan solusi yang harus dilakukan, tapi kurangnya penguasaan terhadap materi prasyarat menjadi suatu hambatan. Hal tersebut mengakibatkan baik siswa 1 maupun siswa 2 menyerah begitu saja. Sehingga dapat disimpulkan bahwa kemampuan untuk membangun keterampilan dasar meliputi mempertimbangkan suatu sumber masih tergolong rendah baik bagi siswa 1 maupun siswa 2. Perlu ditingkatkan kembali untuk menguasai materi prasyarat, sehingga jika materi prasyarat yang dimiliki siswa cukup baik akan mempermudah siswa dalam mengembangkan kemampuan berpikir matematisnya.

\section{KESIMPULAN}

Berdasarkan hasil penelitian dan analisis serta pengolahan data yang telah diperoleh mengenai kesulitan siswa dalam menyelesaikan soal kemampuan berpikir kritis matematis pada materi lingkaran disebabkan oleh kurangnya pemahaman konsep dan kesulitan siswa pada kemampuan berpikir kritis matematis ada pada indikator membangun keterampilan dasar meliputi mempertimbangkan kredibilitas suatu sumber. Self efficacy siswa sudah tergolong cukup melihat dari bagaimana siswa menjawab soal yang diberikan. Terdapat hubungan yang signifikan antara self efficacy terhadap kemampuan berpikir kritis matematis pada materi lingkaran.

\section{DAFTAR PUSTAKA}

Hendriana, H., Rohaeti, E. E., \& Hidayat, W. (2017). Metaphorical Thinking Learning and Junior High School Teachers' Mathematical Questioning Ability. Journal on Mathematics Education, 8(1), 55-64.

Hendriana, H., Hidayat, W., \& Ristiana, M. G. (2018, January). Student teachers' mathematical questioning and courage in metaphorical thinking learning. In Journal of Physics: Conference Series (Vol. 948, No. 1, p. 012019). IOP Publishing.

Hendriana, H., Rohaeti, E., \& Sumarmo, U. (2017). Hard Skills dan Soft Skills Matematik Siswa. Bandung: PT Refika Aditama.

Hidayat, W. (2011). Meningkatkan Kemampuan Berpikir Kritis dan Kreatif Matematik Siswa Melalui Pembelajaran Kooperatif Think-Talk-Write (TTW) (Doctoral dissertation, Universitas Pendidikan Indonesia).

Hidayat, W. (2012). Meningkatkan Kemampuan Berpikir Kritis dan Kreatif Matematik Siswa SMA Melalui Pembelajaran Kooperatif Think-Talk-Write (TTW). In Seminar Nasional Penelitian, Pendidikan dan Penerapan MIPA.

Malia, Dodik, M., \& Reny, W. (2017). Pengaruh Model Pembelajaran Reciprocal Teaching Terhadap Kemampuan Pemahaman Konsep Matematika Siswa Kelas VIII SMP Negeri 11 Lubuklinggau Tahun Pelajaran 2016/2017, 1-14.

Novianty, D. A. (2017). Pengaruh Pendekatan Problem Posing terhadap Kemampuan Berpikir Kritis Matematis Siswa SMP.

Nurjaman, A. (2015). Meningkatkan Kemampuan Komunikasi Matematik Siswa SMP Melalui Model Pembelajaran Kooperatif Tipe Think Pair Share (TPS), 9, 16-25.

Rahmi, S., Nadia, R., Hasibah, B., \& Hidayat, W. (2017). The Relation between Self-Efficacy toward Math with the Math Communication Competence. Infinity Journal, 6(2), 177182. 
370 Nurazizah, \& Nurjaman, Analisis Hubungan Self Efficacy ...

Sumarmo, U., Hidayat, W., Zukarnaen, R., Hamidah, M., \& Sariningsih, R. (2012). Kemampuan dan Disposisi Berpikir Logis, Kritis, dan Kreatif Matematik (Eksperimen terhadap Siswa SMA Menggunakan Pembelajaran Berbasis Masalah dan Strategi Think-Talk-Write). Jurnal Pengajaran MIPA, 17(1), 17-33.

Suwarma, D. M. (2009). Suatu Alternatif Pembelajaran Kemampuan Berpikir Kritis Matematika. Jakarta: Cakrawala Maha Karya.

Tresnawati, T., Hidayat, W., \& Rohaeti, E. E. (2017). Kemampuan Berpikir Kritis Matematis dan Kepercayaan Diri Siswa SMA. Symmetry: Pasundan Journal of Research in Mathematics Learning and Education, 2(2), 39-45. 